\title{
Seasonal characterization of antioxidant responses in plants of Ipomoea nil cv. Scarlet O'Hara
}

\author{
Ferreira, ML. ${ }^{a} *$ and Domingos, M. $^{b}$ \\ ${ }^{a}$ Universidade Nove de Julho - UNINOVE, Av. Adolfo Pinto, 109, Barra Funda, CEP 01156-050, São Paulo, SP, Brazil \\ ' Instituto de Botânica, CP 68041, CEP 04045-972, São Paulo, SP, Brazil \\ *e-mail: mauecologia@yahoo.com.br
}

Received August 31, 2011 - Accepted December 1, 2011 - Distributed November 30, 2012

(With 2 figures)

\begin{abstract}
Reactive oxygen species can be produced in leaf cells during normal aerobic metabolism or in a variety of exogenous factors, which may cause oxidative damage to plants, unless they have an efficient antioxidant defense system, consisting of enzymatic and non-enzymatic substances. This work raised the hypothesis that plants of Ipomoea nil cv. Scarlet O'Hara, a native species and ornamental vine of the tropics, might tolerate oxidative stress factors imposed by natural fluctuations in weather conditions through changes in the antioxidant profile.The objective of this study was to determine the variations in three leaf antioxidants in plants growing inside a greenhouse without air pollutants and exposed to varying meteorological conditions throughout the four seasons of the year and to observe if such variations are related to the oscillations in meteorological factors. Four experimental campaigns were carried out, one in each season of 2006. Each campaign lasted 28 days and started with 45 plants. Ascorbic acid (AA) concentrations and superoxide dismutase (SOD) and peroxidase (POD) activities were determined in leaves of five plants in nine sampling days of each campaign. The antioxidant responses oscillated throughout the year. The highest values were found during the spring. This seasonal antioxidant profile was associated to variations in temperature, relative humidity and global radiation. Plants of this cultivar may then tolerate oxidative stress naturally imposed by meteorological conditions.
\end{abstract}

Keywords: climber plant, ascorbic acid, superoxide dismutase, peroxidase, meteorological factors.

\section{Caracterização sazonal de respostas antioxidativas em plantas de Ipomoea nil cv. Scarlet O’Hara}

\section{Resumo}

As espécies reativas de oxigênio podem ser produzidas em células de folhas durante o metabolismo aeróbico normal ou o sob uma diversidade de fatores exógenos que, por sua vez, podem causar danos oxidativos às plantas, a menos que estas tenham um eficiente sistema de defesa antioxidativo, formado por substâncias enzimáticas e não enzimáticas. Neste trabalho, levantou-se a hipótese de que as plantas de Ipomoea nil cv. Scarlet O'Hara, uma espécie trepadeira ornamental e nativa dos trópicos, podem tolerar fatores de estresse oxidativo imposto por oscilações naturais nas condições meteorológicas por meio de mudanças no perfil antioxidativo. Assim, este trabalho objetivou determinar as variações em três espécies antioxidantes foliares em plantas crescidas em casa de vegetação sob ar filtrado e expostas a condições meteorológicas variáveis ao longo das quatro estações do ano de 2006, bem como verificar se tais variações estão relacionadas às oscilações de fatores meteorológicos. Para tanto, realizaram-se quatro campanhas experimentais. Cada campanha durou 28 dias e começou com 45 plantas. Concentrações de ácido ascórbico (AA) e as atividades de superóxido dismutase (SOD) e peroxidase (POD) foram determinadas em folhas de cinco plantas distintas e retiradas da casa de vegetação em nove dias de amostragem de cada campanha. As respostas antioxidativas oscilaram durante todo $\mathrm{o}$ ano, sendo os maiores valores encontrados durante a primavera. Este perfil sazonal de antioxidantes foi associado às variações de temperatura, umidade relativa e radiação global. As plantas desta cultivar podem, então, tolerar o estresse oxidativo naturalmente imposto pelas condições meteorológicas.

Palavras-chave: planta trepadeira, ácido ascórbico, superóxido dismutase, peroxidase, fatores meteorológicos. 


\section{Introduction}

Some plants may tolerate oscillations in the abiotic conditions of the environment where they are growing more than others, which may subject them to an oxidative stress induced by increased contents of reactive oxygen species in plant tissues (De Gara et al., 2010; Foyer and Noctor, 2011). This occurs due to the differential efficiency of antioxidants in neutralizing the noxious effects of ROS to the cells. It is well known that antioxidants of the ascorbate-glutathione cycle play an important role in this defensive process, during both normal metabolic activities, in the photoreduction of the $\mathrm{O}_{2}$ into the thylakoid or by exogenous reasons and the entrance of ozone to the plant (Burkey et al., 2006; Iriti and Faoro, 2008; De Gara et al., 2010; Foyer and Noctor, 2011).

Ascorbic acid, a non-enzymatic antioxidant, besides regulating cell division, is one of the most important antioxidants in plants. Hydrogen peroxide $\left(\mathrm{H}_{2} \mathrm{O}_{2}\right)$ is decomposed while this antioxidant is oxidized to dehydroascorbic acid, a reaction that is mediated by ascorbate peroxidase. AA is also considered an important molecule against ozone due to its occurrence in the apoplast, once this pollutant enters the plant predominantly through the stomata and reacts immediately with water intensifying the ROS formation. Other non-enzymatic molecules implicated into the Halliwelle Asada cycle may also be relevant to neutralize the ROS. The glutathione, for example, serves as a substrate to remove $\mathrm{H}_{2} \mathrm{O}_{2}$ by glutathione peroxidase, converting it to an oxidized form, which prevents lipid peroxidation and reacts with radicals hydroxyl and singlet oxygen. It also protects the $\mathrm{SH}$ groups of essential cell metabolism enzymes and has the important role of regenerating the AA. (Foyer and Noctor, 2005, 2011).

As a scavenger of radical superoxide, the enzyme superoxide dismutase (SOD) is another important tool to defend plants against oxidative stress, SOD converts $\mathrm{O}_{2}^{-}$ to $\mathrm{H}_{2} \mathrm{O}_{2}$, and then $\mathrm{H}_{2} \mathrm{O}_{2}$ is converted to $\mathrm{H}_{2} \mathrm{O}$ by ascorbate peroxidase (APX), by means of the oxidation of AA or by catalases (CAT) (Iriti and Faoro, 2008; De Gara et al., 2010; Lin et al., 2011).

The formation and level of such antioxidants may be seasonality marked in response to changes in the environmental conditions, even in the absence of anthropic interferences. This is plausible because the seasonality in solar irradiation, photoperiod, temperature and relative humidity, among other meteorological factors, as well as influencing the stomata aperture, regulates the photosynthesis and respiration processes on chloroplasts and mitochondria and thus the natural production of ROS in the cells. Variations in the levels of antioxidants may also occur during the aging of the plant, which occurs concomitantly with higher protein degradation, and loss of chlorophyll (Bulbovas et al., 2005; Ohe et al., 2005; Foyer and Noctor, $2005 ; 2011)$. Therefore, we may raise the hypothesis that variations in antioxidant responses throughout the life cycle occurs, making the plant more or less susceptible to seasonal variations in diverse environmental stressors. In theory, this hypothesis is also valid for the ornamental cultivar Scarlet O'Hara of Ipomoea nil, which is the aim of the present study, due to its climbing habit and high sensitivity to ozone, an interesting characteristic for biomonitoring purposes (Nouchi and Aoki, 1979). Therefore, the range of antioxidant responses to naturally varying meteorological conditions should be known before its usual application as an ornamental or bioindicator plant in a determined environment.

Thus, the aims of this work were: 1) To determine the variations in three antioxidative species in leaves of Ipomoea nil cv. Scarlet O'Hara, throughout their development in the four seasons of the year; 2) To observe if such variations are related to the oscillations in temperature, relative humidity and solar radiation throughout the seasons.

\section{Material and Methods}

\subsection{Plant cultivation and experimental campaigns}

Seeds of Ipomoea nil cv. Scarlet O'Hara were commercially acquired (from CN Seeds LTD, www. cnseeds.co.uk) and derived from the same lot. They were germinated in a mixture of a commercial substrate mainly consisting of bark of Pinus (Plantimax-Eucatex) and fine vermiculite, at a ratio of $3: 1$, respectively. Seedlings containing the cotyledonal leaves were transplanted to plastic vases with the same substratum mixture. At this moment, a small wooden prop was placed to support the plants during their growth.

Four experimental campaigns were carried out, one in each season of 2006. The summer, autumn, winter and spring campaigns were done in February/March, May/June, August/September and November/December respectively.

Each campaign started when plants had at least seven expanded leaves including the cotyledonal ones, approximately one month after seedling transplantation, and lasted 28 days. It was initiated with 45 plants produced as described above. During the period of 28 days, in the time zero and in intervals between three or four days (totalizing nine sampling days), the concentrations of ascorbic acid (AA) and the activity of superoxide dismutase (SOD) and peroxidase (POD) were determined in the $5^{\text {th }}, 6^{\text {th }}$ and $7^{\text {th }}$ older leaves of the main stem of five plants.

During cultivation and experimental periods, the plants had an adequate irrigation ensured by capillarity thorough nylon strings and received periodic fertilization by aqueous nutrient solution prepared according to Epstein (1975).

All the experimental campaigns, from the germination of the seeds to plant sampling, were carried out in a greenhouse supplied by filtered air located at the Institute of Botany. This is in the Southeastern region of the São Paulo city, exactly at $23^{\circ} 38^{\prime} 28.8^{\prime} ' \mathrm{~S}$ and $46^{\circ} 37^{\prime} 15.8^{\prime}$ ' $\mathrm{W}$; $805 \mathrm{~m}$ above sea level (Fernandes et al., 2002).

Air conditioning regulated daily maximum temperatures of air so that it varied in a similar way to that in the external environment. Average values of temperature, humidity and radiation during each campaign indicated that the plants were exposed to an acceptable range of these meteorological parameters and to similar environmental conditions observed in São Paulo (Table 1). 
Table 1. Average temperature relative humidity and global radiation, as well as minimum and maximum values between parentheses, inside the greenhouse during the four campaigns carried out in 2006.

\begin{tabular}{lccc}
\hline \multicolumn{1}{c}{ Campaigns } & Temperature $\left({ }^{\circ} \mathbf{C}\right)$ & Relative humidity $(\%)$ & Global radiation $\left(\mathbf{M J} / \mathbf{m}^{2}\right)$ \\
\hline Summer & $26.5(18.0-34.1)$ & $71(35-87)$ & $9.8(4.9-13.1)$ \\
Autumn & $26.1(17.4-34.5)$ & $72(30-87)$ & $6.7(3.6-8.7)$ \\
Winter & $23.4(16.1-34.5)$ & $66(18-87)$ & $8.7(1.7-12.2)$ \\
Spring & $27.9(19.2-34.0)$ & $72(28-87)$ & $10.4(5.0-17.4)$ \\
\hline
\end{tabular}

\subsection{Analytical procedures}

AA was determined in fresh leaves $(0.2 \mathrm{~g})$, homogenized with $12 \mathrm{~mL}$ of EDTA-Na $(0.07 \%)$ and oxalic acid $(0.5 \%)$. The mixture was centrifuged at $40000 \mathrm{~g}$ for 30 minutes at $2{ }^{\circ} \mathrm{C}$. An aliquot of the supernatant was added to $2.5 \mathrm{~mL}$ of DCPiP $(0.02 \%)$ and absorbance was measured spectrophotometrically at $520 \mathrm{~nm}$ (first lecture). After adding $0.05 \mathrm{~mL}$ of ascorbic acid (1\%), the second absorbance measurement was performed. Both absorbance measurements were used to estimate the ascorbic acid content (Keller and Schwager, 1977).

SOD activity was also determined in frozen leaves at $-40{ }^{\circ} \mathrm{C}(0.4 \mathrm{~g})$, homogenized with $12 \mathrm{~mL}$ of potassium phosphate buffer $(50 \mathrm{mM} \mathrm{pH} \mathrm{7,5)}$ with EDTA-Na $1 \mathrm{mM}$, $\mathrm{NaCl} 50 \mathrm{mM}$ and ascorbic acid $1 \mathrm{mM}$ in the presence of a pinch of polyvinyl polypyrrolidone (PVPP) $2 \%$ and centrifuged at $22000 \mathrm{~g}$ for 25 minutes at $2{ }^{\circ} \mathrm{C}$. The activity of SOD was assayed by measuring the SOD inhibition of the NBT photochemical reduction (Osswald et al., 1992). Each reaction mixture contained $0.5 \mathrm{~mL}$ of EDTA-Na $0.54 \mathrm{mM}, 0.8 \mathrm{~mL}$ of potassium phosphate buffer $(0.1 \mathrm{M}$, $\mathrm{pH} 7.0), 0.5 \mathrm{~mL}$ of methionine $0.13 \mathrm{mM}, 0.5 \mathrm{~mL}$ of NBT $0.44 \mathrm{mM}, 0.2 \mathrm{~mL}$ of riboflavin $1 \mathrm{mM}$ and $0.2 \mathrm{~mL}$ of leaf extract. The samples were incubated for 20 minutes under a fluorescent lamp $(80 \mathrm{~W})$. The absorbance of the reaction mixture was determined at $560 \mathrm{~nm}$. A similar mixture lacking the leaf extract was used as a control, and a dark control mixture served as a blank. The enzymatic activity was expressed as the amount of extractable needed to inhibit the reduction of NBT by $50 \%$.

POD activity was determined in frozen leaves at $-40{ }^{\circ} \mathrm{C}$ $(0.3 \mathrm{~g})$, homogenized with $12 \mathrm{~mL}$ potassium phosphate buffer (0.1 M, pH 7.0) in the presence of a pinch of polyvinyl polypyrrolidone (PVPP) $2 \%$. The homogenate was centrifuged at $40000 \mathrm{~g}$ for 30 minutes at $2{ }^{\circ} \mathrm{C}$. The Peroxidases were determined in a reaction mixture of plant extracts, $0.1 \mathrm{M}$ potassium phosphate buffer ( $\mathrm{pH}$ 5.5) and fenylendiamine $(1 \%)$, to which was added an aliquot of $\mathrm{H}_{2} \mathrm{O}_{2}(0.3 \%)$, according to Klumpp et al. (1989). Unspecific POD activity was measured spectrophotometrically following the increase in absorbance (dE) at $485 \mathrm{~nm}$ due to the formation of an $\mathrm{H}_{2} \mathrm{O}_{2}$-POD complex at two different times in the linear reaction curve.

\subsection{Statistical analyses}

Differences in antioxidant responses among leaves in each sampling day were searched by means of one way analyses of variance. Two way analyses of variance with two factors were carried through in order to identify differences between the seasons (factor 1) and throughout the time in each season (factor 2). In all the cases, the posthoc multiple comparison test (Student-Newman Keuls) was applied if the analysis of variance indicated significant differences. When necessary, the data were transformed to reach the normal distribution and/or equal variances. Principal component analysis (PCA) was carried out in order to evaluate the overall variability of antioxidant responses in leaves of I. nil cv. Scarlet O'Hara throughout the four seasons of the year, searching for evidence of seasonality. Analyses of correlation (Pearson) were carried out to determine the relations and antioxidant responses in the leaves and meteorological conditions inside the greenhouse in each experimental campaign and between the antioxidant responses in plants analyzed during the overall experimental period.

\section{Results and Discussion}

In most of the cases, no significant differences in the antioxidant responses were found among the leaves analyzed in each sampling day during each experimental campaign, which might characteristically indicate a leaf aging effect (data not shown). This result opposes the expectation that younger leaves should present more efficient capacity of defense than older leaves in the same plant. Moreover, the young leaf generally presents a high metabolic rhythm due to its stage of development, which should intensify the formation of reactive oxygen species and demands a higher efficiency of the antioxidative system. Ohe et al. (2005), for example, observed that older leaves of Nicotiana tabacum cv. Xanthi exposed to conditions of photoxidative stress presented a lower content of AA and lesser activity of ascorbate-peroxidase in the chloroplasts when compared with younger leaves.

As a consequence of the absence of differential responses among leaves, the antioxidants measured in each sampling day were presented in Figure 1 and Table 2 as average per plant. Such responses oscillated in their levels throughout the year. The contents of AA in the plants of I. nil cv. Scarlet O'Hara exposed during the summer campaign gradually increased over time, reaching maximum values after seven days of experiments and then gradually decreased. The leaf AA concentration remained almost constant during plant growth in the autumn campaign. The winter campaign was characterized by a significant high concentration of the AA in plants taken on the last day of sampling. The leaf AA varied throughout all 28 days of the experiment performed during the spring, reaching maximum values after 11 to 14 days (Figure 1a). On average, no significant variations in the leaf levels of AA were observed among the seasons (Table 2). 

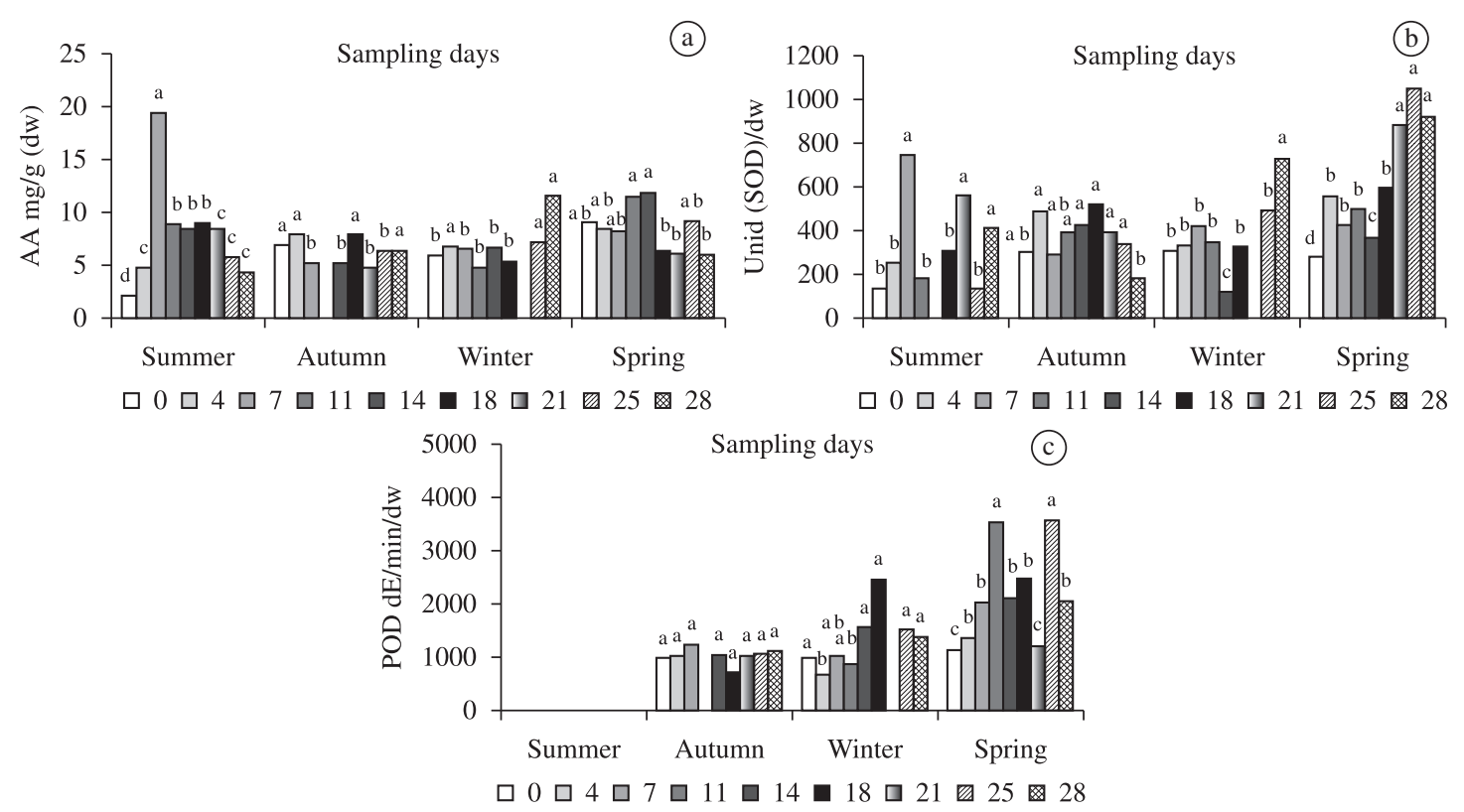

Figure 1. Average profiles of antioxidants in plants of I. nil Scarlet O' Hara, in nine days of analysis, throughout 28 days of each experimental campaign carried out in 2006. a) Concentrations of ascorbic acid (AA). b) Activity of superoxide dismutase (SOD); c) Activity of peroxidases (POD). Distinct letters indicate significant differences in antioxidant responses among the sampling days in each season. \# Data not available.

Table 2. Average values of ascorbic acid and activity of superoxide dismutase and peroxidases in plants of $I$. nil 'Scarlet O' Hara, throughout 28 days of each experimental campaign carried out in 2006.

\begin{tabular}{lccc}
\hline Campaign & $\begin{array}{c}\text { AA } \\
(\mu \mathrm{g} / \mathbf{g} \mathbf{d w})\end{array}$ & $\begin{array}{c}\text { SOD } \\
(\mathbf{U n i d} / \mathbf{g} \text { dw })\end{array}$ & $\begin{array}{c}\text { POD } \\
(\mathbf{d E} / \mathbf{m i n} / \mathbf{g} \mathbf{d w})\end{array}$ \\
\hline Summer & $7.9^{\mathrm{a}}$ & $332.6^{\mathrm{b}}$ & $\#$ \\
Autumn & $6.3^{\mathrm{a}}$ & $370.5^{\mathrm{b}}$ & $1008.4^{\mathrm{b}}$ \\
Winter & $6.9^{\mathrm{a}}$ & $384.0^{\mathrm{b}}$ & $1300.2^{\mathrm{b}}$ \\
Spring & $8.6^{\mathrm{a}}$ & $619.8^{\mathrm{a}}$ & $2153.3^{\mathrm{a}}$ \\
\hline
\end{tabular}

Distinct letters indicate differences in antioxidant responses among the different seasons of the year.

The activity of SOD in plants of I. nil cv. Scarlet O'Hara oscillated during the summer campaign. It was significantly higher after 04, 21 and 28 days of this campaign. During the autumn, the activity of SOD was relatively constant in the plants. A gradual decrease in its levels occurred from the $21^{\text {st }}$ day on, reaching the lowest value in the last day of analysis. Similar to AA, the activity of SOD was significantly low in plants sampled in the middle of the winter campaign and reached the maximum average value in plants sampled in the last day of sampling. The activity of SOD gradually increased over time during the spring campaign, reaching maximum values in the three last days of the sampling (Figure 1b). On average, significantly higher value of SOD was observed in the plants analyzed during the spring campaign (Table 2).
The activity of POD in plants of $I$. nil cv. Scarlet O'Hara did not significantly differ in plants sampled during the autumn campaign. During the winter campaign, significantly low activity of POD was measured in the plants taken after four days of exposure and high after 18 days of experiment. POD showed a clear oscillatory profile during the spring campaign. Its activity gradually increased during the first 11 days and then decreased until the $21^{\text {st }}$ day. Similar oscillation was also observed at the end of this campaign (Figure 1c). A significantly higher average value of POD was also observed in the plants analyzed during the spring campaign (Table 2).

The principal component analysis (PCA) carried out with the biological measurements (content of AA and activities of SOD and POD) explained $93.7 \%$ of the variability of the data in axis one and two $(55.9 \%$ in axis one and $37.8 \%$ in axis two). The level of both enzymatic antioxidants (SOD and POD) was strongly related with axle one; contrarily AA was weakly related with it. The graph from this analysis confirmed the occurrence of an evident seasonality in the antioxidant responses in plants of I. nil cv. Scarlet O'Hara, mainly marked by the enzymatic antioxidants (Figure 2). The sampling units of the spring campaign were grouped on the positive side of axle 1 , and were characterized by the highest values of SOD and POD. On the other hand, the sampling units of the other seasonal experiments were generally grouped at the opposite side of this axle. Plants generally presented a low activity of SOD, but higher levels of POD during the autumn and winter and a low activity of both SOD and POD during the summer. 


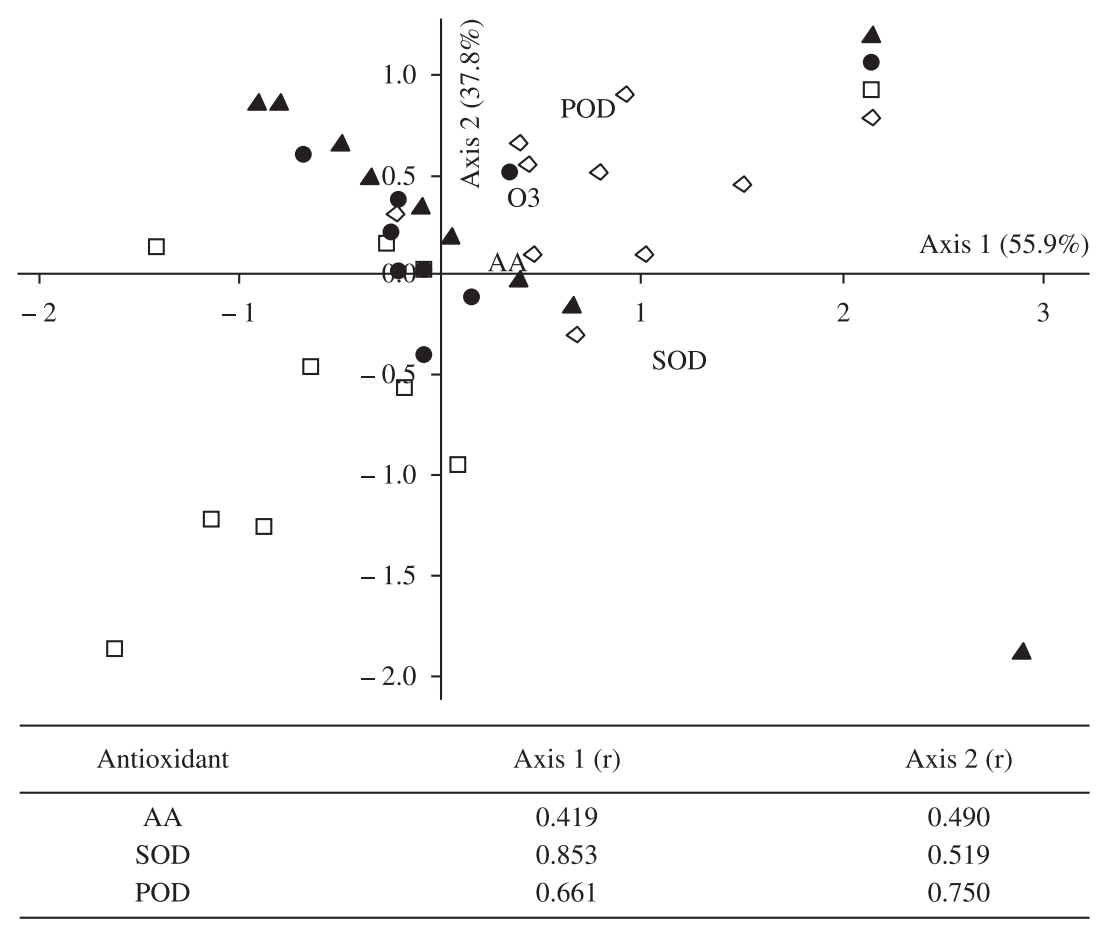

Figure 2. Principal component analysis of antioxidants in leaves of $I$. nil 'Scarlet O'Hara' throughout 28 days of each experimental campaign carried out in 2006. AA - Concentration of ascorbic acid; SOD - Activity of superoxide dismutase; POD - Activity of peroxidases. The table shows the correlations ( $r$ ) of the average values of antioxidant responses with the axles one and two of the Principal Component Analysis.

Finally, the analyses of the Pearson correlation indicated that the variations in antioxidants were more strongly stimulated by daily oscillations in climatic factors such as temperature, humidity and radiation five days before plant sampling throughout the different seasons of the year (Table 3), showing that the relation between the changes in the environment and the plant antioxidant responses is time dependent. These correlations showed to be the clearest among those tested between leaf antioxidants and environmental conditions zero to ten days before the leaf sampling (data not shown). Similar results were obtained by Dafré-Martinelli et al. (2011).

No significant relations were found between the antioxidants and meteorological conditions during the summer campaign. Air temperature positively influenced the content of AA during the autumn and winter and the activity of both enzymes during spring. Relative humidity (RH) positively influenced the levels of AA in the autumn, the activity of SOD and POD in the winter and SOD again in the spring. A significant and negative relation was observed between $\mathrm{RH}$ and AA in the spring period. Solar radiation was negatively related to the concentrations of AA during the autumn and winter and positively related to AA and SOD in the spring. In brief, the differential intensity of the meteorological conditions seemed to affect the prooxidant/antioxidant equilibrium in the cells of $I$. nil cv. Scarlet O'Hara, as pointed out by Muggli (1993). Bulbovas et al. (2005) also observed no uniform relationship between antioxidant responses in
Table 3. Pearson correlation coefficients ( $r$ ) between antioxidant responses in plants of $I$. nil cv. Scarlet O'Hara, throughout 28 days of each experimental campaign carried out in 2006 and daily values of temperature (T), relative humidity (RH) and global radiation (GR) five days before leaf sampling.

\begin{tabular}{cccc}
\hline $\begin{array}{c}\text { Season } \\
\text { antioxidant }\end{array}$ & T (r) & RH (r) & GR (r) \\
\hline Summer & & & \\
AA & -0.07 & 0.25 & -0.05 \\
SOD & -0.12 & 0.41 & -0.29 \\
POD & $\#$ & $\#$ & $\#$ \\
Autumn & & & \\
AA & $0.36^{*}$ & $0.36^{*}$ & $-0.42^{*}$ \\
SOD & 0.05 & 0.24 & -0.25 \\
POD & 0.01 & -0.13 & 0.15 \\
Winter & & & \\
AA & 0.19 & $0.51^{*}$ & $-0.33^{*}$ \\
SOD & 0.00 & $0.40^{*}$ & -0.27 \\
POD & 0.07 & $0.35^{*}$ & -0.13 \\
Spring & & & \\
AA & -0.20 & $-0.40^{*}$ & $0.65^{*}$ \\
SOD & $0.54 *$ & $0.37^{*}$ & $0.44^{*}$ \\
POD & $0.49 *$ & 0.19 & -0.17 \\
\hline
\end{tabular}

*Significant coefficient $(\mathrm{p}<0.05)$. \# Data not available. 
plants of Caesalpina echinata Lam. cultivated in the same greenhouse used in the present study and oscillations in air temperature and relative humidity, which in turn regulate the stomata movement. The authors could similarly attribute the varying antioxidant responses to greater or minor rates of plant photosynthesis, transpiration and respiration.

The highest values of antioxidants found in the spring campaign performed with plants of $I$. nil may indicate two antagonist situations. They could have reflected ideal environmental conditions for growth of $I$. nil cv. Scarlet O'Hara. If so, the meteorological conditions observed inside the greenhouse during that period promoted high rates of photosynthesis in the plants. Consequently the formation of EAO should have been intensified, demanding increased antioxidant responses. In fact, this positive influence is expected according to Foyer and Noctor (2005, 2011), who affirmed that these seasonal oxidation-reduction relations may be part of how plants perceive and respond to environmental triggers.

However, the highest levels of antioxidants in plants of $I$. nil grown during the spring may also have reflected environmental stressing conditions instead of ideal conditions for growth. According to Takahashi and Badger (2011), extreme amounts of radiation and an increase of radiation absorption of UV create a situation of stress that may firstly affect the photosystem II reaction center. This fact may have occurred in the present study during spring, considering that it was characterized by the highest values of solar radiation and temperature inside the greenhouse in comparison to the meteorological conditions observed in the other seasons and that positive relationships were preponderantly found between the level of the antioxidant responses and solar radiation or temperature during this season. Additionally, Foyer and Noctor (2011) affirmed in their review that ascorbic acid fulfills several important roles in the protection of photosynthesis from the adverse effects of high sunlight. These authors add that the abundance of ascorbate in leaves is regulated both in response to the amount of light available during the photoperiod and the red/far-red ratio of the incident light. The strong positive correlation proved between the concentrations of ascorbic acid and global radiation observed in the present study during the spring points particularly to this kind of protection of the $I$. nil against the solar radiation in excess.

Other authors also observed such seasonality in antioxidants in response to the meteorological characteristics of each season of the year. Gilham and Dodge (1987) showed that the ascorbate levels, ascorbate-peroxidase and gluthatione-redutase in leaves of Pisum satium (L.) under control conditions presented an outstanding seasonal variation. Low activities and concentrations of antioxidants marked respectively the winter and summer times. The authors associated these results to differences in the density of light flow. During the hottest seasons of the year, the respiratory rates of the plants are higher and can also induce an increasing antioxidant response due to a consequent higher ROS production in mitochondria. This respiratory increase is associated with an increase in the NADH synthesis (Dizengremel et al., 2009), which is related to the production of enzymes such as SOD. For example, Zhang et al. (2008) found a significant copperzinc SOD increase in Elsholtzia haichowensis during the enhancement of respiration rates induced by some stress factors. Therefore, plants have evolved various mechanisms to cope with the stresses imposed by naturally fluctuating environmental conditions, generally modulated by the gene expression and synthesis of compounds that may result in higher stress tolerance (Ahmad et al., 2010). Willekens et al. (1994) showed that ozone promoted an increase in the mRNA levels, resulting in an enhancement of the synthesis of glutathione peroxidase and some isoenzymes of CAT in plants of $N$. plumbaginifolia. Kwon et al. (2002) demonstrated that the simultaneous expression of $\mathrm{Cu} / \mathrm{Zn}$ SOD and APX genes in tobacco chloroplasts enhanced tolerance to oxidative stress compared to the expression of either of these genes alone. Gillespie et al. (2011) also observed significant changes in the transcription of specific proteins and antioxidant responses in plants of Glycine $\max$ (soybean) exposed to acute doses of ozone.

The antioxidant profile observed in plants of $I$. nil cv. Scarlet O'Hara during the summer campaign seemed to mark more characteristically the rhythm of growth and aging of the whole plant than the influence of daily meteorological conditions, as commented by Musselman and Massman (1998), Ohe et al. (2005) and Foyer and Noctor $(2005,2011)$. Maximum leaf AA concentrations and SOD activity after seven days of experiments might have indicated maximum cell division and growth rate of plants, followed by an evident aging process.

Analyses of Pearson correlation finally showed that the antioxidant responses of I. nil 'Scarlet O' Hara' were themselves positively related throughout the four campaigns $[\mathrm{AA} \times \mathrm{SOD}(\mathrm{r}=0.37, \mathrm{p}=0.03) ; \mathrm{AA} \times \mathrm{POD}(\mathrm{r}=0.44$, $\mathrm{p}=0.02)$ and SOD $\times$ POD $(r=0.44, p=0.02)]$. This fact suggests that integrated plant responses to ambient variations occurred reflecting the good capacity against oxidative stress, as found by Foyer et al. (1997). It means that the high activity of SOD led to an increase in the $\mathrm{H}_{2} \mathrm{O}_{2}$ production that was, in turn, eliminated by other antioxidative substances of the cycle ascorbate-glutathione as AA and peroxidases (more specifically ascorbate-peroxidase).

The results from this study revealed an evident seasonality in the antioxidant responses of plants of Ipomoea nil 'Scarlet O' Hara' growing throughout the four seasons of the year. These oscillating responses could be associated to a gradient of environmental conditions imposed by temperature, relative humidity and solar radiation. The action of determined ambient stimulations, such as that, can demand greater or minor efficiency of the antioxidative system.

Therefore, plants of this cultivar, growing in the greenhouse under filtered air and submitted to similar ambient conditions of São Paulo, are capable of defending themselves against oxidative stress naturally imposed by the climate.

Acknowledgements - We would like to thank FAPESP (Fundação de Amparo à Pesquisa no Estado de São Paulo) for giving financial support and to CNPq (Conselho Nacional de Pesquisa e Desenvolvimento) for offering a MSc scholarship to the first author. 


\section{References}

AHMAD, R., KIM, Y-E., KIM, M-D., KWON, S-Y., CHO, C., LEE, H-S. and KWAK, SS., 2010. Simultaneous expression of choline oxidase, superoxide dismutase and ascorbate peroxidase in potato plant chloroplasts provides synergistically enhanced protection against various abiotic stresses. Physiologia Plantarum, vol. 138, p. 520-533. PMid:20059737. http://dx.doi.org/10.1111/j.13993054.2010.01348.x

BULBOVAS, P., RINALDI, MCS., DELITTI, WBC. and DOMINGOS, M., 2005. Variação sazonal em antioxidantes em folhas de plantas jovens de Caesalpinia echinata Lam. (paubrasil). Revista Brasileira de Botânica, vol. 28, no. 4, p. 687-696.

BURKEY, KO., NEUFELD, HS., SOUZA, L., CHAPPELKA, AH. and DAVISON, AW., 2006. Seasonal profiles of leaf ascorbic acid content and redox state in ozone-sensitive wildflowes. Environmental Pollution, vol. 14, p. 427-434.

DAFRÉ-MARTINELLI, M., NAKAZATO, RK., DIAS, APL., RINALDI, MCS. and DOMINGOS, M., 2011. The redox state of Ipomoea nil "Scarlet O'Hara" growing under ozone in a subtropical area. Ecotoxicology and Environmental Safety, vol. 74, p. 1645-1652. PMid:21741708. http://dx.doi.org/10.1016/j. ecoenv.2011.06.001

DE GARA, L., LOCATO, V., DIPIERRO, S. and PINTO, MC., 2010. Redox homeostasis in plants. The challenge of living with endogenous oxygen production. Respiratory Physiology \& Neurobiology, vol. 173, p. 513-519. PMid:19778366. http:// dx.doi.org/10.1016/j.resp.2010.02.007

DIZENGREMEL, P., LE THIEC, D., HASENFRATZ-SAUDER, MP., VAULTIER, MN., BAGARD, M. and JOLIVET, Y., 2009. Metabolic-dependent changes in plant cell redox power after ozone exposure. Plant Biology, vol. 11, no. 1, p. 35-42. http:// dx.doi.org/10.1111/j.1438-8677.2009.00261.x

EPSTEIN, E., 1975. Nutrição mineral das plantas: princípios e perspectivas. Tradução e notas de E. Malvolta. São Paulo: Editora da Universidade de São Paulo. Livros técnicos e científicos.

FERNANDES, AJ., REIS, LAM. and CARVALHO, A., 2002. Caracterização do meio físico. In BICUDO, DC., FORTI, MC. and BICUDO, CEM. (Orgs.). Parque Estadual das fontes do Ipiranga (PEFI): unidade de conservação ameaçada pela urbanização de São Paulo. São Paulo: Editora Secretaria do Meio Ambiente do Estado de São Paulo. p. 51-62.

FOYER, CH., LOPES-DELGADO, H., DAT, JF. and SCOTT, IN., 1997. Hydrogen peroxide and glutathione associated mechanism of acclimatory stress tolerance and signalling. Plant Physiology, vol. 10, p. 241-254.

FOYER, CH. and NOCTOR, G., 2005. Oxidant and antioxidant signalling in plants: a re-evaluation of the concept of oxidative stress in a physiological context. Plant, Cell and Environment, vol. 28, p. 1056-1071. http://dx.doi.org/10.1111/j.1365-3040.2005.01327.x

FOYER, CH. and NOCTOR G., 2011. Ascorbate and glutathione: the heart of the redox hub. Plant Physiology, vol. 155, p. 2-18. http://dx.doi.org/10.1104/pp.110.167569

GILHAM, DJ. and DODGE, AD., 1987. Chloroplast superoxide and hydrogen peroxide scavenging systems from pea leaves: Seasonal variation. Plant science, vol. 50, p. 105-109. http:// dx.doi.org/10.1016/0168-9452(87)90145-2

GILLESPIE, KM., ROGERS, A. and AINSWORTH, EA., 2011. Growth at elevated ozone or elevated carbon dioxide concentration alters antioxidant capacity and response to acute oxidative stress in soybean (Glycine max). Journal of Experimental Botany, vol. 62, no. 8, p. 2667-2678. PMid:21282325. http://dx.doi. org/10.1093/jxb/erq435

IRITI, M. and FAORO, F., 2008. Oxidative stress, the paradigm of ozone toxicity in plants and animals. Water, Air and Soil Pollution, vol. 187, p. 295-301.

KELLER, T. and SCHWAGER, H., 1977. Air pollution and ascorbate. European Journal of Forest Pathology, vol. 7, p. 338-350. http://dx.doi.org/10.1111/j.1439-0329.1977.tb00603.x

KLUMPP, G., GUDERIAN, R. and KÜPERS, K., 1989. Peroxidaseund superoxiddismutase- aktivität sowie Prolingehalte von fichtenna-deln nach belastung mit $\mathrm{O}_{3}, \mathrm{SO}_{2}$ und $\mathrm{NO}_{2}$. European Journal of Forest Pathology, vol. 19, p. 84-97. http://dx.doi. org/10.1111/j.1439-0329.1989.tb00238.x

KWON, SY., JEONG, YJ., LEE, HS., KIM, JS., CHO, KY., ALLEN, RD. and KWAK, SS., 2002. Enhanced tolerances of transgenic tobacco plants expressing both superoxide dismutase and ascorbate peroxidase in chloroplasts against methyl viologenmediated oxidative stress. Plant Cell Environment, vol. 25, p. 873-882. http://dx.doi.org/10.1046/j.1365-3040.2002.00870.x

LIN, CC., JIH, PJ., LIN, HH., LIN JS., CHANG, LL., SHEN, YH. and JENG, ST., 2011. Nitric oxide activates superoxide dismutase and ascorbate peroxidase to repress the cell death induced by wounding. Plant Molecular Biology, vol. 77, p. 235-249. PMid:21833542. http://dx.doi.org/10.1007/s11103-011-9805-x

MUGGLI, R., 1993. Free radicals tissue damage: the protective role of antioxidant nutrients. In CORONGIU, F., BANNI, S., DESSI, MA. and RICE-EVANS, C. (Ed.). Free radicals and antioxidantes in nutrition. London: Richelieu Press. p. 189-250.

MUSSELMAN, RC. and MASSMAN, W.J., 1998. Ozone flux to vegetation and its relationship to plant response and ambient air quality standards. Atmospheric environmental, vol. 33, p. 65-73. http://dx.doi.org/10.1016/S1352-2310(98)00127-7

NOUCHI, I. and AOKI, K., 1979. Morning glory as a photochemical oxidant indicator. Environmental Pollution, vol. 18, p. 289-303. http://dx.doi.org/10.1016/0013-9327(79)90024-7

OHE, M., RAPOLU, M., MIEDA, T., MIYAGAWA, Y., YABUTA, Y., YOSHIMURA, K. and SHIGEOKA, S., 2005. Decline in leaf photooxidative-stress tolerance with age in tobacco. Plant science, vol. 168, p. 1487-1493. http://dx.doi.org/10.1016/j. plantsci.2005.01.020

OSSWALD, WF., KRAUS, R., HIPELLI, S., BENS, B., VOLPERT, R. and ELSTNER, EF., 1992. Comparasion of the enzymatic activities of dehydroascorbic acid redutase, glutathione redutase, Catalase, peroxidase and superoxide dismutase of healthy and damaged spruce needles (Picea abies (L.) Karst). Plant physiology, vol. 139, p. 742-748. http://dx.doi.org/10.1016/S0176-1617(11)81721-9

TAKAHASHI, S. and BADGER, MR., 2011. Photoprotection in plants: a new light on photosystem II damage. Trends in Plant Science, vol. 16, no. 1, p. 53-60. PMid:21050798. http://dx.doi. org/10.1016/j.tplants.2010.10.001

WILLEKENS, H., VAN CAMP, W., VAN MONTAGU, M., INZÉ, D., LANGEBARTELS, C. and SANDERMANN JUNIOR, H., 1994. Ozone, sulfur dioxide, and ultraviolet B have similar effects on mRNA accumulation of antioxidant genes in Nicotiana plumbaginifolia L. Plant Physiology, vol. 106, p. 1007-1014. PMid:12232381. PMCid:159625.

ZHANG, HX., XIA, Y., WANG, GP. and SHEN, ZG., 2008. Excess copper induces accumulation of hydrogen peroxide and increases lipid peroxidation and total activity of copper-zinc superoxide dismutase in roots of Elsholtzia haichowensis. Planta, vol. 227, p. 465-475. PMid:17909854. http://dx.doi.org/10.1007/ s00425-007-0632-x 
